\title{
Electrochemical Copper Deposition from an
}

\section{Ethaline- $\mathrm{CuCl}_{2}$.2 $\mathrm{H}_{2} \mathrm{O}$ DES}

\author{
Swatilekha Ghosh and Sudipta Roy* \\ School of Chemical Engineering and Advanced Materials, Merz Court, Newcastle University, \\ Newcastle upon Tyne, NE2 7RU, UK \\ *corresponding author \\ email: sudipta.roy@ncl.ac.uk
}

\begin{abstract}
$\mathrm{Cu}$ electroplating was carried out using a pure ethaline melt, a 1:2 ratio of choline chloride and ethylene glycol, at room temperature by potentiostatic and galvanostatic methods. Hydrated cupric chloride was added to the pure ethaline melt. Polarisation data for cupric ion reduction to copper was collected using an $\mathrm{RDE}$ to determine where metal deposition was feasible. Smooth $\mathrm{Cu}$ deposits were obtained at $-4.7 \times 10^{-3} \mathrm{~A} / \mathrm{cm}^{2}$ using $0.2 \mathrm{M} \mathrm{CuCl}_{2} .2 \mathrm{H}_{2} \mathrm{O}$ at 25 ${ }^{\circ} \mathrm{C}$ at a current efficiency of $(95 \pm 5) \%$ at a rotation speed of $700 \mathrm{rpm}$. XRD analysis of the deposit showed a polycrystalline face centered cubic structure with (111) texture. The crystalline size was $66 \pm 10 \mathrm{~nm}$ with some internal strain. EDX analysis showed the presence of carbon and chlorine with copper in the deposit, which was due to the break-down of the DES. Several deposition processes were carried out from a single bath to examine bath stability. The bath was found to be stable when a soluble anode was employed, and became unstable when an insoluble anode was used due to other reactions proceeding at the cathode.
\end{abstract}


Keywords: choline chloride, ionic liquids, ethaline, copper deposition, electroplating, electrodeposition

\section{Introduction}

Electrodeposition of copper has been carried out from aqueous solutions for a variety of applications [1-4]. Aqueous acid and alkaline solutions have been employed due to their high current efficiency $[1,4,5]$, good throwing power $[6,7]$, relatively high plating rates $[1,2]$ and low cost [1]. Some of these electrolytes have come under scrutiny for their environmental impact [8-9], and in certain cases, the associated health and safety issues [10]. In the past decade researchers have proposed ionic liquids (ILs) as alternative to such aqueous solutions $[11,12]$. An IL can be defined as a mixture consisting solely of cations and anions with a melting point of $100{ }^{\circ} \mathrm{C}$ and below [13], and excellent books and reviews are available on this subject $[13,14]$. A range of ILs is available in market, of which some have been employed for electrodeposition [15-18], which has raised the possibility of their use for copper plating.

The earliest tests of copper deposition were carried out using chloroaluminate salts $[19,20]$ which showed the feasibility of copper and copper alloy deposition [21, 22] from chloroaluminate ionic liquids. These researchers systematically established the speciation of metallic ions in the solvent, and how the thermodynamic parameters influence the formation and stabilisation of the electroreducible species [21,23].

In parallel, a group in Kyoto University proposed trimethyl-n-hexylammonium bis((trifluoromethyl)sulfonyl)amide (amide based) molten salt, which was more tolerant to air or water [23]. They showed that cupric species in solution existed in $\mathrm{Cu}^{+}$or $\mathrm{Cu}^{2+}$, and that the electron transfer reaction was mainly with the cuprous species [26], due to a 
comproportionation reaction between $\mathrm{Cu}$ metal and cupric species in solution $[25,26]$. The same authors showed that $\mathrm{Cu}-\mathrm{Sn}$ could be formed using these ionic liquids by "contact" deposition of Sn onto a copper electrode at sufficiently high temperature. The alloy formed due to fact that deposition could be carried out at sufficiently high temperatures where the IL was still stable and where $\mathrm{Sn}$ diffused into $\mathrm{Cu}[27]$.

This initial promise of ionic liquids for copper electrodeposition has led to further research. Much of this research has been to develop a deeper understanding of speciation in solution $[28,29]$, their electrochemical behaviour [30] the influence of temperature on physical properties [18, 23] and the effect of impurities such as water [28, 29]. Novel additives [31], ionic liquid systems [32], and methodologies [33] have been deployed to obtain desirable deposits.

However, for practical metal plating purposes, choline chloride $(\mathrm{ChCl})$ based ILs is one of the cheapest and easily accessible, which makes them attractive [15-17]. Choline chloride $(\mathrm{ChCl})$ based ILs consist of $\mathrm{C}_{5} \mathrm{H}_{14} \mathrm{NOCl}$ with a hydrogen bond donor (HBD) such as $\mathrm{CH}_{4} \mathrm{~N}_{2} \mathrm{O}$ (urea), $\mathrm{C}_{2} \mathrm{H}_{2} \mathrm{O}_{4}$ (oxalic acid), $\mathrm{C}_{3} \mathrm{H}_{8} \mathrm{O}_{3}$ (glycerol), $\mathrm{CH}_{2}(\mathrm{COOH})_{2}$ (malonic acid), or $\mathrm{C}_{2} \mathrm{H}_{6} \mathrm{O}_{2}$ (ethylene glycol) to form a deep eutectic solvent (DES) or melt [13, 17, 34-41]. It has been shown that these solvents are characterised melting points lower than room temperature [35]. They exhibit reasonable solubility for wide range of metal salts $[13,17]$ and show good tolerance to water and air $[13,34,36]$. The IL derived from choline chloride and ethylene glycol, used in this study, is known as ethaline. The corresponding melts using oxalic acid, urea and malonic acid are known as oxaline, reline and maline, respectively. The practical promise of $\mathrm{ChCl}$ based DES's has led to a variety of metal plating investigations [38-45], and a wide variety of metals such as $\mathrm{Cu}, \mathrm{Ni}, \mathrm{Pd}, \mathrm{Sn}$ have been deposited. 
Previous studies for $\mathrm{Cu}$ from $\mathrm{ChCl}$-based have been carried out to determine the solubility and equilibrium potentials [36], electrochemical characteristics [18, 36, 37, 39-41], and the effect of metal content and current density on deposit properties [40, 41]. A spectrophotmetric study of copper speciation in these solvents showed that $\left[\mathrm{CuCl}_{4}\right]^{2-}$ species is formed in aqueous chlorine chloride solutions [29], which has been verified through electrochemical studies [45]. Electrochemical kinetic studies using copper chloride in an ethaline solution revealed that the diffusion coefficient of $\mathrm{Cu}^{+}$and $\mathrm{Cu}^{2+}$ species in solution were substantially different, and that the charge transfer reaction of $\mathrm{Cu}^{+}$to $\mathrm{Cu}^{0}$ was about three times faster than $\mathrm{Cu}^{2+}$ to $\mathrm{Cu}^{+}$[30]. Tsuda et.al. [18] showed that $\mathrm{Cu}_{2} \mathrm{O}$ could be directly dissolved in a reline melt, and that copper could be deposited via a single electron transfer.

Despite the progress in scientific understanding on metal deposition from $\mathrm{ChCl}$ based electrolytes, the performance of these electrolytes for long term metal deposition is relatively unexplored. Recently, Popescu and co-workers have carried out electrodeposition of copper on graphite substrates from ethaline, reline and maline at $80^{\circ} \mathrm{C}$ [41]. They used a hydrate-free $\mathrm{CuCl}_{2}$ salt and deposited copper of a nominal thickness between 2.9 to $6.5 \mu \mathrm{m}$. These authors commented on the lack of good deposits from most of these melts, although they did not attribute it to any specific cause. They found deposits from ethaline at a low current density, i.e.,- $0.005 \mathrm{~A} / \mathrm{cm}^{2}$, to provide the most homogeneous deposit. Based on XRD analysis the deposits were found to contain pure crystalline copper.

More recently $\mathrm{Gu}$ and co-workers have also reported on $\mathrm{Cu}$ electrodeposition from an ethaline melt [31]. They first mixed only hydrated cupric chloride salts in ethaline; however the solution was found to be unstable and formed green coloured precipitate within six hours of plating [31]. They highlighted the need of ethylene diamine as an additive in order to achieve solution stability [31], although this additive can raise the melting point of the mixture [36]. 
They plated smooth, compact and fine-grained deposits from this additive containing ethaline solution.

These plating studies show that more knowledge on copper deposition is required before DES can be employed for copper plating. For example, these studies indicate that copper deposition is possible only by maintaining a suitably high temperature or by adding chemicals to ethaline. In addition, it seems that the precipitation can occur from ChCl-based liquids, which is contrary to previous reports. The electrolysis of ethaline has also shown that the ionic liquid itself can break down at the anode and cathode, which can also affect the long term viability of plating process [46].

In order to resolve some of these issues we have tested if $\mathrm{Cu}$ deposition can be carried out using a copper chloride-ethaline melt by potentiostatic or galvanostatic plating methods at room temperature for relatively long periods of time. In order to use easily available chemicals which are commonly used in the plating industry, hydrated $\mathrm{CuCl}_{2}$ was mixed in a pure ethaline melt was used. In order to identify the electrochemical behaviour of copper deposition from this solution, copper polarisation data were collected using a rotating disc electrode (RDE). Thereafter, copper was deposited at a low carbon steel substrate using the same rotating disc. Deposits up to $15 \mu \mathrm{m}$ in thickness were plated from this solution. All deposits were analysed using standard materials analysis techniques. In order to detect changes in the ethaline melt, a separate experiment was carried out, where a number of plating operations from the same bath was performed. Changes in solvent coloration, precipitation and any associated changes within the deposit were monitored during this time period.

\section{Experimental}

\subsection{Melt Preparation}


Ethaline was prepared by mixing analytical grade choline chloride $\left(\mathrm{C}_{5} \mathrm{H}_{14} \mathrm{NOCl}\right)$ of $>98 \%$ purity and ethylene glycol $\mathrm{C}_{2} \mathrm{H}_{6} \mathrm{O}_{2}$ in 1:2 ratio from Sigma-Aldrich without any purification. This mixture was kept in a thermostatic heater at $40{ }^{\circ} \mathrm{C}$ and stirred for 24 hours to form a colourless liquid and subsequently, stored in an airtight glass bottle to minimize the interaction of the electrolyte with air. Later 0.05 or $0.2 \mathrm{M} \mathrm{CuCl}_{2} .2 \mathrm{H}_{2} \mathrm{O}$ was added to ethaline. These concentrations were chosen because stable metal ion melts are obtained [29, 41], and they represent low and high concentrations of metal loading.

The speciation of copper in solution was determined by determining the coloration of the melt. The colour of the solution was found to be yellow-orange to dark brown, depending on the concentration of $\mathrm{CuCl}_{2} \cdot 2 \mathrm{H}_{2} \mathrm{O}$. The yellow-orange-brown colour has been shown to be due to the formation of $\left[\mathrm{CuCl}_{4}\right]^{2-}$ ion $[28,29]$, which has been verified by earlier electrochemical studies. Although there are waters of hydration associated with the metal salt, prior studies have shown that the speciation of cupric ions remains unaffected up to a hydration of 50 mol\% [29]. In this work the hydration remained close to $10 \%$, and therefore the speciation of hydrated $\mathrm{CuCl}_{2}$ is expected to be the same as the hydrate-free one. Table 1 shows the chemical reaction leading to the formation of ionic melt, and the subsequent formation of $\mathrm{Cu}^{2+}$ species in the DES.

\subsection{Polarisation Experiments}

To determine the reduction potential and maximum current that can be used to deposit copper, polarisation experiments were carried out. A standard three electrode cell using a platinum rotating disc, (Radiometer Analytical), with a Pt mesh as counter electrode was used. A silver wire served as a quasi-reference electrode. The cell, as shown in Figure 1, was jacketed, and the temperature was maintained using a water bath. Potential scans were performed using a computer controlled $\mu$ Autolab instrument. The scan range was maintained between $-0.7 \mathrm{~V}$ to 
$+0.6 \mathrm{~V}$ and the scan rate was $30 \mathrm{mV} / \mathrm{s}$, which is sufficient to obtain quasi-potentiostatic data for the reduction of copper species [30].

\subsection{Electrodepositon Experiments}

Electrodeposition experiments were performed using a $0.9 \mathrm{~cm}$ diameter low carbon steel disc (i.e. $0.64 \mathrm{~cm}^{2}$ ) inserted in the $\mathrm{RD}$ apparatus. This enabled one to polish the disc before an experiment, and extract the disc at the end of the operation for further inspection and analysis. Potentiostatic plating was perfomed using the Autolab instrument and galvanostatic deposition was enabled with PL320 constant power supply (Thurlby-Thandar). The plating temperature was $25^{\circ} \mathrm{C}$. For galvanostatic deposition the anode was either a $\mathrm{Pt}$ mesh or $\mathrm{Cu}$ sheet.

The concentration of $\mathrm{CuCl}_{2} .2 \mathrm{H}_{2} \mathrm{O}$ was fixed at either $0.05 \mathrm{M}$ or $0.2 \mathrm{M}$, in order to determine the effect of metal ion concentration on deposit properties. RDE speeds were fixed at $700 \mathrm{rpm}$ or $1300 \mathrm{rpm}$ to observe the effect of mass transfer on deposit morphology. Deposition time was set at $3600 \mathrm{~s}$, when a deposit of about $15 \mu \mathrm{m}$ was obtained. The obtained deposits were analysed using standard materials analysis. Optical microscopy was used to detect homogeneity of the deposit, scanning electron microscopy revealed the morphology, and xray diffraction revealed crystalline structure.

\subsection{Electrolyte stability}

To examine the long term deposition of $\mathrm{Cu}$ from the ethaline melt, galvanostatic copper deposition was carried out from the same solution for a period of a month. Large excursions in temperature were avoided by maintaining the solution at $25^{\circ} \mathrm{C}$ throughout the operation. The melt was monitored for changes in colour, gas evolution at the electrodes or phase separation. Concurrently, the cell potential, deposit properties and current efficiency was 
monitored during each plating experiment. Two different anodes, one inert and the other soluble, were used in these experiments.

\section{Results}

\subsection{Linear polarisation experiments}

Figure 2 shows the polarisation data for copper reduction at Pt electrode from 0.05 and $0.2 \mathrm{M}$ $\mathrm{CuCl}_{2} \cdot 2 \mathrm{H}_{2} \mathrm{O}$ mixed in ethaline melts. The two reduction waves in the forward sweep correspond to the first and second electron transfer [29, 30, 40, 45]. The first reduction step commences at $+0.5 \mathrm{~V}$ and the second step is observed at $-0.4 \mathrm{~V}$, which is in good agreement with earlier findings [41]. In the reverse sweep, a stripping peak is observed above $-0.4 \mathrm{~V}$ corresponding to the formation of $\mathrm{Cu}^{+}$from metallic copper. Based on these polarisation data it can be inferred that copper deposition will proceed at potentials $<-0.4 \mathrm{~V}$.

Interestingly, the stripping current for the oxidation of $\mathrm{Cu}^{0}$ to $\mathrm{Cu}^{+}$commences whilst the current is still cathodic. For that, one needs to consider that the region where the stripping current is observed lies in the potential regime where the reduction of cupric ions to cuprous ions proceeds. In essence, the following two reactions proceed simultaneously at the electrode $1^{\text {st }}$ reduction step $: \mathrm{Cu}(\mathrm{II})+\mathrm{e}^{-} \quad \rightarrow \mathrm{Cu}(\mathrm{I})$, and

$2^{\text {nd }}$ oxidation step: $\mathrm{Cu}(0) \quad-\quad \mathrm{e}^{-} \quad \rightarrow \mathrm{Cu}(\mathrm{I})$,

Since the total current of the system is a summation of the partial currents for copper oxidation and reduction, it appears that the stripping current in the cathodic domain. Such voltammery behaviour is common during copper deposition from chloride in aqueous systems [47], and standard for many other electrochemical redox systems [48].

A second notable point is that the reduction currents for copper increase as the rotation speed or the copper concentration is increased, and a first current plateau is observed below $0.3 \mathrm{~V}$, 
and a second plateau is observed below $-0.5 \mathrm{~V}$, exhibiting mass transfer control for the two separate reaction steps. As per the Levich equation, a limiting current density, $\mathrm{i}_{\mathrm{L}}$, is related to bulk concentration, $C_{b}$ and rotating speed, $\omega$, by:

$\mathrm{i}_{\mathrm{L}}=\mathrm{k} C_{b} \omega^{1 / 2}$

where $\mathrm{k}$ is constant depending on the diffusion coefficient and viscosity. The plateau currents at $-0.6 \mathrm{~V}$, as shown in figures 2 (a) and (b) are listed in Table 2. The ratio of the plateau currents, as calculated from those computed from experimental values (in the figure) can be compared against those expected from theory. The data in the last two columns show ratio of limiting currents obtained from the scan experiments in figure 2 and equation 1 . The ratios are similar to that expected when the metal is plated under mass transfer control.

Since other reactions, such as break down of the IL can occur if the mass transfer limiting current is exceeded [46], when galvanostatic plating is carried out, the current applied should be lower or equal to that of the second reduction step. If the metal plating current is set below the first reduction step, then only $\mathrm{Cu}^{+}$would be formed, and no metal would be deposited. During galvanostatic plating, therefore, the applied current was set between these two limiting currents.

The current efficiency was calculated by calculating the charges of the anodic and cathodic parts of the potential scans using the data shown in figure 2 . The ratio of the total amount of charge plated and stripped during the scan was determined by integrating the current vs time data for the four different experiments in figure 2. The deposition efficiency value was found to be $97 \%$, which is close to those observed by other researchers [28]. It is known that that comproportionation reactions can proceed in certain ionic liquids. However, in those studies current efficiencies are found to nearly twice as the expected value [26]. The current efficiency values obtained in our work show that comproportionation reactions do not occur. 


\subsection{Electrodeposition Experiments}

Potentiostatic plating of $\mathrm{Cu}$ was carried out at $-0.6 \mathrm{~V}$ vs. an $\mathrm{Ag}$ wire, i.e. within the mass transfer controlled region. This potential was chosen because the metal plates at the mass transfer limiting rate, i.e. the fastest possible rate, which is useful for industrial processes. Figure 3 shows some of the typical results obtained in these set of experiments. For a low concentration of copper in solution, i.e., $0.05 \mathrm{M}$, the deposit was poor and thin (A), which indicates that such low metal loadings are unsuitable for copper deposition.

Figure 3 (B) and (C) show copper deposits obtained using $0.2 \mathrm{M} \mathrm{CuCl}_{2} .2 \mathrm{H}_{2} \mathrm{O}$ in the DES at two different RDE rotation speeds. The micrographs show that a reasonably good deposit is obtained at the lower rotation speed of $700 \mathrm{rpm}$, although rough deposits are obtained at the higher rotation speed. These experiments showed that copper deposition under potentiostatic conditions is achievable when the current density is low - typically $-6.0 \times 10^{-3} \mathrm{~A} / \mathrm{cm}^{2}$, because the deposit roughens quickly at higher plating currents.

In order to carry out galvanostatic deposition, a current where copper deposition is feasible has to be selected. Since the potentiostatic experiments showed that reasonably high quality copper deposition can proceed close to the mass transfer limiting current at $700 \mathrm{rpm}$, current densities were set between $-3 \times 10^{-3}$ and $-6 \times 10^{-3} \mathrm{~A} / \mathrm{cm}^{2}$, which correspond to the lower and higher limits of galvanostatic plating as described in section 3.1. A dense and homogeneous deposit, as shown in Fig 4(A) was obtained at a current density of $-4.7 \times 10^{-3} \mathrm{~A} / \mathrm{cm}^{2}$. Current efficiency, as determined by gravimetry, was greater than $95 \%$, in excellent agreement with the charge balance measurements.

\subsection{Characterisation of $\mathrm{Cu}$ deposits}


$\mathrm{SEM} / \mathrm{EDX}$ analysis on the deposit obtained by galvanostatic deposition at $-4.7 \times 10^{-3} \mathrm{~A} / \mathrm{cm}^{2}$ was performed to determine the morphology and composition of the deposit. The micrograph of the section shown in fig 4(B) indicates that the deposit consists of very small grains and is reasonably dense. EDX analysis showed that the deposit contained mostly copper (96\%), with small amounts of chlorine and carbon. The inclusion of chlorine and carbon ( $2 \%$ each) within the deposit could have proceeded from the co-reduction of the ionic liquid.

The XRD pattern along with corresponding (hkl) value for each of the peak obtained for the deposit is shown in figure 5. The spectra show different peaks for pure copper, with other peaks arising from the steel substrate and PTFE holder. No carbides of copper were detected. For a powder $\mathrm{Cu}$ sample the ratio of intensity for (111): (200): (220): (311) : (222) peaks is 100: $46: 20: 17: 5$ [49]. Figure 5 shows an intensity ratio of $100: 12: 21: 13: 6$, showing a textured deposit with mostly (111) orientation. Similar crystalline structure was obtained for $\mathrm{Cu}$ deposit obtained from ethaline- $\mathrm{CuCl}_{2}$ melts by $\mathrm{Gu}$ and co-workers [31].

On closer inspection of figure 5, one notices that (111), (220), and (311) peaks exhibit doublets. The zoom of these doublets are presented in figure 6 . These could be due to presence of $K \alpha_{1}$ and $K \alpha_{2}$ components in incident and diffracted beams from $\mathrm{Cu}$ source [50] as monochromatization was not carried out during the XRD scan. According to Braggs' law the relationship between the positions of the diffraction peaks of the doublets should be $[50,51]$,

$$
\frac{\sin \theta_{1}}{\lambda_{K \alpha_{1}}}=\frac{\sin \theta_{2}}{\lambda_{K \alpha_{2}}}
$$

For (111), (220), and (311) peaks the values of $\theta_{1}$ are $43.37^{\circ}, 74.18^{\circ}$ and $89.9^{\circ}$ and $\theta_{2}$ are $43.46^{\circ}, 74.38^{\circ}, 90.26^{\circ}$ respectively, and $\lambda_{\mathrm{K} \alpha 1}$ is 1.540 and $\lambda_{\mathrm{K} \alpha 2}$ is $1.544 \AA$. For these peaks as shown in fig. 6 , the obtained $\sin \theta_{1} / \lambda_{\mathrm{Ka} 1}$ value is determined as $0.52 \pm 0.07$ and the obtained 
$\sin \theta_{2} / \lambda_{\mathrm{K} \alpha 2}$ value is determined as $0.45 \pm 0.1$. The intensity ratio of the two peaks, based on $I_{K \alpha_{1}}: I_{K \alpha_{2}}$, is 1.7:1 which is in reasonable agreement with an expected value of 2:1 [50].

The crystallite size of the material can be determined using the Scherrer equation [51],

$D=\frac{0.9 \lambda}{\beta^{\prime} \cos \theta}$

Where $\mathrm{D}=$ grain size or crystallite size, $\beta^{\prime}=$ full line broadening at the half of the maximum intensity (FWHM), $\lambda=x$-ray wave length. Using the more intense peaks of (111), (220), and (311) an average crystalline size was computed. Using the line broadening of the peaks shown in figures 6 a to c, the value of the crystallite size was determined to be $66 \pm 10 \mathrm{~nm}$. This is nearly $50 \%$ smaller than those reported for copper deposits from aqueous solutions $(115 \pm 15$ $\mathrm{nm})[52]$.

As the electron micrograph showed, there are a number of defects, i.e., within the deposit producing strain. The strain $(\varepsilon)$ in a crystalline structure is defined as [53]

$\varepsilon=\frac{D^{\prime}-D}{D}$

Where $\mathrm{D}=$ strain free lattice spacing and $\mathrm{D}^{\prime}=$ strained lattice spacing. The strain contribution to the line broadening can be determined by the Williamson-Hall method [54]. The strain value was determined using same peaks as those used for grain size calculation, from the line broadening. The relationship between crystalline size, strain and line broadening is,

$\frac{2 \cos \theta \cdot \beta}{\lambda}=\frac{0.9}{D^{\prime}}+\varepsilon \frac{2 \sin \theta}{\lambda}$

From which $\varepsilon$ is calculated explicitly by rearranging equation 5

$\therefore \varepsilon=\frac{\beta}{\tan \theta}-\left(\frac{\lambda}{D^{\prime}} \times \frac{1}{2 \sin \theta} \times 0.9\right)$ 
The value of strain was determined to be $0.0022 \pm 0.0007$. This is broadly similar to other electrodeposited films; for example for electroless plating it is $0.0028 \pm 0.0002$ [55]. For much thinner $\mathrm{Cu}$ films, i.e. $0.8 \mu \mathrm{m}$, obtained by DC magnetron sputtering (on Si wafers) a value of $0.0018 \pm 0.0002[55]$ has been reported.

\subsection{Bath Stability}

In order to examine if the electrolyte became unstable during long term use, a number of deposition experiments were carried out using the same electrolyte. Plating was carried out galvanostatically using the same electrochemical parameters reported in section 3.2. Plating operations were continued for one month, where a total 24 plating runs, amounting to $27 \mathrm{hrs}$ of deposition from the bath, were carried out. During these experiments approximately 0.018 moles of $\mathrm{Cu}^{2+}$, corresponding to a thickness of nearly $200 \mu \mathrm{m}$ of metal on the steel substrate, was deposited out from the electrolyte.

Table 3 summarises the variations in cell voltage during the entire operation. The current efficiency and deposit morphology remained relatively unchanged showing the stability of the process. However, there were occasions when the cell potential showed some fluctuation, which was accompanied by changes in current efficiency. These fluctuations were observed when a dimensionally stable Pt anode was employed. It was found that fluctuations occurred when the metal ion concentration in the DES fell. Smooth, uniform deposits and higher current efficiency was regained when additional $\mathrm{CuCl}_{2} \cdot 2 \mathrm{H}_{2} \mathrm{O}$ was added to increase the cupric ion content. This suggests that decreasing metal ion content in the melt caused problems, and also that the process could be stabilised by directly adding metal salt to the IL. 
The instabilities mentioned in the previous paragraph could be explained by considering the breakdown of the DES itself. It has been shown that reactions such as $\mathrm{H}_{2}$ evolution can occur at the cathode due to the the discharge of protons [46]. In addition, water breakdown can also occur releasing hydrogen gas, and $\mathrm{OH}^{-}$[46]. These reactions cannot be averted by simply avoiding the use of hydrated salts, since ethaline itself is hygroscopic, and the inclusion of water can actually reduce the breakdown of choline [46]. In our experiments gas evolution at the cathode was observed, which could point to the formation of hydrogen leading the some degree of breakdown of choline due to formation of $\mathrm{OH}^{-}$. Both oxygen evolution and the breakdown of ethylene glycol at the anode could also lead to changes in the solvent. However, in our case, since the addition of hydrated copper chloride stabilised the system, the cathode breakdown products seem to be more crucial.

When a soluble copper anode was used, no signs of process instability or changes in deposit quality were detected throughout the operation. Although metal salt was not replenished in this solution, towards the end of the plating run (of one month), a red powdery layer formed on the top surface of the electrolyte. This layer could be copper, copper chloride or copper oxide because it has been shown that these products can be directly dissolved into a DES [18, 56]. Such a powdery layer had been observed previously in our laboratory while mixing the metal salt in the DES; at that time it was found that $\mathrm{CuCl}_{2}$ was was separating from the ionic liquid due to exceeding its solubility limit [45].

The increasing copper content in the DES for the experiment leading to powder formation could be due to the difference in current consumed by copper reduction vs. cupric ions introduced into the solution due to dissolution of the copper anode. Since the current efficiency for copper deposition is $95-97 \%$ and that for dissolution $100 \%, \mathrm{Cu}^{2+}$ in the DES 
would steadily increase. Over a long period of time $\mathrm{Cu}^{2+}$ would build up in solution. This could lead to the separation of copper, copper oxides or chlorides from the DES.

Monitoring colour changes of the electrolytes with respect to the solution freshly prepared for deposition was employed as a method of detecting speciation changes within the electrolyte. Figure 7 shows the electrolyte immediately after preparation, (1), and those with a soluble (2A) and inert (2B) anode after a period of metal deposition. The decreasing metal ion concentration in solution (using the inert anode) corresponds to faded colour. A deeper coloration is observed when a soluble anode is used, corresponding to a higher metal content in the IL. . The orange-brown coloration shows that the speciation of copper in solution remains as $\left[\mathrm{CuCl}_{4}\right]^{2-}$ during the long term plating process. Although fresh $\mathrm{CuCl}_{2} \cdot 2 \mathrm{H}_{2} \mathrm{O}$ had been added to the solution, at no point was green or blue colouration, associated with the formation of aquo or aquo-chloro complexes [28, 29] was observed.

\section{Discussion}

The electrochemical behaviour of copper deposition shows that the system is reversible at low and high $\mathrm{Cu}^{2+}$ loading, as was reported in earlier studies [13, 29, 30, 35, 45]. In addition the reduction of copper from the cupric species in solution takes place in two steps - the first to the cuprous ion, and thereafter to copper. This behaviour is comparable to that observed in aqueous chloride solutions [47]. Both reactions are mass transfer controlled, and hence the maximum plating current of copper is fixed by fluid agitation and copper concentration in solution.

It is important to compare the plating current achievable in this melt vis-à-vis an aqueous $\mathrm{CuCl}_{2}$ plating system containing similar amount of copper. For a $0.2 \mathrm{M} \mathrm{CuCl}_{2}$, operating at a rotation speed of $700 \mathrm{rpm}$, a mass transfer limiting current of $-0.146 \mathrm{~A} / \mathrm{cm}^{2}$ is calculated 
based on a diffusion coefficient of $6.0 \times 10^{-6} \mathrm{~cm}^{2} / \mathrm{s}$ [47], and a kinematic viscosity of 0.01 $\mathrm{cm}^{2} / \mathrm{s}$. This is two orders of magnitude higher than that achieved in our work, mainly due to the high viscosity and low diffusivity of ethaline [45]. This means that plating rates of copper at room temperature from an ethaline melt will be an order of magnitude lower than those achieved for aqueous electrolytes. This limitation of ionic liquids for metal plating has also been pointed out by other researchers $[24,26]$.

Copper deposits obtained from the melt showed some interesting characteristics. The deposited copper was very pure, but contained $2 \%$ carbon and chloride. These data are also indicative of a reaction involving the solvent, as mentioned above. In order to cross check the potentials where the IL breaks down, polarisation of pure ethaline was performed, the data for which are presented in figure 8 . The figure shows that the IL breaks down below a potential of $-0.7 \mathrm{~V}$, as reported previously $[30,46]$. However, low currents are observed at much lower cathodic potentials, i.e. at $\sim-0.3 \mathrm{~V}$, indicating that some degree of break down begins at relatively low potentials. Since the potential for copper deposition is below $-0.4 \mathrm{~V}$, the carbon and chlorine detected in the deposits are likely to be IL breakdown products.

The grain size, as observed in the scanning electron micrograph is small, approximately 100 to $200 \mathrm{~nm}$. The grain size does not increase as the deposit grows, showing that new nuclei are generated during the electrodeposition process. The continued generation of nuclei may be due to the co-reduction of the ionic liquid along with copper which may block grain growth; the smaller crystallite size in comparison to those obtained from aqueous solutions is also supportive of this observation.

An interesting question arises regarding the bath instability found in our experiments and those reported by Gu et. al. [31]. Those researchers comment of the precipitate formed at the 
bottom of their container, which was green in colour with an accompanied change in the solvent colouration to green-yellow [31]. Guosheng et al. [29] and Vreese et. al. [30], in two separate studies using two different ionic liquids have shown that blue, green and greenyellow colouration of cupric species is associated with aquo or cholo-aquo complexes. Therefore, the precipitates found in Gu's work can be attributed to the formation of chloroaquo species, which was not found in our experiments. During long term copper plating, the colour of the DES remained orange-brown, which confirmed that stability of tetradentate chloro-species. The difference in the two sets of experiments is the copper content in the DES; Gu et. al. formed a solution which contained $0.45 \mathrm{M} \mathrm{CuCl}_{2} \cdot 2 \mathrm{H}_{2} \mathrm{O}$, which was feasible at the plating temperature used by them, i.e. $80^{\circ} \mathrm{C}$ [31]. This would mean that the water content in that solution was much higher, close to $25 \%$, which was much higher than that used in our experiments.

In order to achieve a long term stable plating process, an electrolyte which is stable for long periods of time is required. Our long term plating experiments show that copper can be deposited at room temperature from a pure ethaline $-\mathrm{CuCl}_{2} \cdot 2 \mathrm{H}_{2} \mathrm{O}$ melt, although there may be some degree of co-reduction of the melt itself. In addition, if the copper content is maintained at $0.2 \mathrm{M}$, the plating parameters and deposit characteristics remain constant. Copper, water and glycol content in solution can vary when inert or soluble anodes are used, leading to changes in melt characteristics. This can be avoided with the use of soluble anodes.

\section{Conclusion}

$\mathrm{Cu}$ was electrodeposited from pure ethaline at room temperature by potentiostatic and galvanostatic methods. Polarisation data showed that copper deposition can be carried out out at potentials below $-0.4 \mathrm{~V}$. Smooth, uniform $\mathrm{Cu}$ deposits were obtained at $-4.7 \times 10^{-3} \mathrm{~A} / \mathrm{cm}^{2}$ using $0.2 \mathrm{M} \mathrm{CuCl}_{2} .2 \mathrm{H}_{2} \mathrm{O}$ at $25^{\circ} \mathrm{C}$ using $\mathrm{RDE}$ speed of $700 \mathrm{rpm}$ by galvanostatic method. The 
current efficiency of the process was $95 \%$. EDX analysis showed that carbon and chlorine were present in the deposit. XRD analysis showed a polycrystalline face centered cubic structure with (111) texture. The crystallite size is $66 \pm 10 \mathrm{~nm}$ with an internal strain of $0.2 \%$. Long term electrodeposition experiments showed the electroactive species remains the same throughout the plating period. However, the use of inert anodes leads to the breakdown of DES, and some degree of breakdown occurs during copper deposition. When soluble anodes are used a brown powder, which could be copper based salts or oxides was found to form.

\section{Acknowledgement:}

S. Ghosh acknowledges an ORS(UK) award and a scholarship from Newcastle University.

\section{References}

1. M. Schlesinger and M. Paunovic (eds.) Modern Electroplating, $4^{\text {th }}$ ed. John Wiley and Sons, Inc (2000).

2. T. Gupta, "Deposition Technologies of Materials for Cu-Interconnects" Copper Interconnect Technology, 2009, pp 223-265, Springer.

3. M.T.S. Nair, L. Guerreoro, O. L. Arenas and P. K. Nair, Applied Surface Science, 150 (1999) 143-151.

4. S. Roy, Surf. Coatings Tech., 105, (1998), 202-205.

5. E. Olander, Electrochemical Products Inc., New Berlin, WI, http://www.epi.com/user/files/AlkalineCyanide-FreeCopperPlating.pdf , accessed on 31/05/2013.

6. R. Walker and S.D. Cook, Surf. Technology, 11 (1980) 189-203.

7. C. Madore, D. Landolt, C. Haßenpflug and J.A. Hermann, Plat. Surf. Finish. 82, (1995) 36-41.

8. REACH directives, http://ec.europa.eu/environment/chemicals/reach/reach intro.htm, accessed on 23/05/2013.

9. S. Roy, S. Yoshihara and G. Zangari, Editors, ECS Trans., 16, Issue 36, "Green Electrodeposition 2", The Electrochemical Society, (2009).

10. Environment Agency, Regulations/licenses/guidance, http://www.environmentagency.gov.uk/default.aspx, accessed on 23/05/2013. 
11. A. P. Abbott, K. J. McKenzie, Phys. Chem. Chem. Phys. 8 (2006) 4265-4279.

12. F. Endres, Phys. Chem. Phys. Chem. 3 (2002) 144-154.

13. F. Endres, A. P. Abbott and D. R. MacFarlane (eds.) 'Electrodeposition from Ionic Liquids', WILEY-VCH Verlag GmbH \& Co. KGaA, Weinheim (2008).

14. H. Ohno (Ed.), Electrochemical Aspects of Oinic Liquids" New York, John Wiley and Sons (2005).

15. T. Tsuda and C. L. Hussey, Interface (2007) 42-49.

16. R. Böck and S.-E. Wulf, Trans. Inst. of Metal Finishing, 87, ((2009) 28-32.

17. A. P. Abbott, K. S. Ryder and U. König, Trans. Inst. of Metal Finishing 86(4), (2008) 196-204.

18. T. Tsuda, L. E. Boyd, S. Kuwabata and C. L. Hussey, J. Electrochem. Soc. 157(8) F96-F103 (2010).

19. C. L. Hussey, Room Temperature Molten Salt Systems, in G. Mamantov (Ed.) "Advances in Molten Salt Chemistry" Vol 20, (Elsevier, New York 1983) pp. 185-230.

20. B. J. Tierney, W. R. Pitner, J. A. Mitchell and C. L. Hussey, J. Electrochem. Soc., 145 (1998) 3110.

21. W. R. Pitner, C. L. Hussey and G. R Stafford, J. Electrochem. Soc., 143, (1996) 130.

22. Q. Zhu and C. Hussey, J. Electrochem. Soc. 149(5) C268-C273 (2002).

23. T. M. Laher and C. L. Hussey, Inorg. Chem., 198322 3247-3251.

24. K. Murase, K. Nitta, T. Hirato and Y. Awakura, J. Appl. Electrochemistry, 31 (2001) 1089-1094.

25. T. Vainikka, D. Lloyd, L. Murtomaki, J. Manzanares, K. Kontturi, Electrochimica Acta, 87 (2013), 739-748.

26. T. Katase, K. Murase, T. Hirato, Y. Awakura, J. Applied Electrochemistry 37 (2007), 339-344.

27. T. Katase, R. Kurosaki, K. Murase, T. Hirato and Y. Awakura, Electrochem. Solid State Letters, 9 (2006) C69-72.

28. L. Guosheng, D. M. Camaioni, J. E. Amonette, Z. C. Zhang, T. J. Johnson, J. A. Fulton, J. Phys. Chem. B, 114, 12614-12622 (2010).

29. P. D. Vreese, N. R. Brooks, K. V. Hecke, L. V. Meervelt, E. Matthijs, K. Binnemans and R. V. Deun, Inorganic Chemistry 51 (2012) 4972-4981.

30. D. Lloyd, T. Vainikka, L. Murtomaki, K. Kontturi, E. Ahlberg, Electrochim. Acta 56 (2011) 4942-4948. 
31. C. D. Gu, Y. H. You, X. L. Wang and J. P. Tu, Surf. and Coatings Tech. 209 (2012) 117-123.

32. I. B. Assaker and M. Dhahbi, J. Molecular Solids, 161 (2011) 13-18.

33. S. Schaltin, N. R. Brooks, L. Stappers, L. D’Urzo, H. Plank, G. Kothleitner, C. Gspan, K. Binnemans, J. Fransaer, J. Electrochem. Soc., 158 (2011) D647-D650.

34. A. P. Abbott, G. Capper, D.L. Davies, R.K. Rasheed and V. Tambyrajah, Chem. Commun. (2003) 70-71.

35. K. E. Ttaib, G. Frisch, K. J. McKenzie, and K. S. Ryder, Phys. Chem. Chem. Phys., 11, (2009) 4269-4277.

36. A.P. Abbott, G. Capper, D.L. Davies, R.K. Rasheed and P.Shikotra, Inorg. Chem. 44 (2005) 6497-6499.

37. A. P. Abbott, G. Capper, K. McKenzie, K. S. Ryder, J. Electroanal. Chem. 599 (2007) 288-294.

38. A. P. Abbott, K. El Ttaib, K. S. Ryder and E. L. Smith, Trans. Met. Finishing, 2008 86(4) 234-240.

39. A. Florea, L. Ancai, S. Costovici, F. Golgovici and T. Visan, Surf. Interface Anal. (2010) 42 1271-1275.

40. A.-M. J. Popescu, V. Constantin, A. Cojocaru and M. Olteanu, Rev. Chim. 62(2) (2011) 206-211.

41. A.-M. J. Popescu, V. Constantin, M. Olteanu, O. Demidenko and K. Yanushkevich, Rev. Chim. 62(6) (2011) 626-632.

42. S. Salome, N. M. Pereira, E. S. Ferreira, C. M. Pereira, A. F. Silva, J. Electroanalytical Chemistry, (2013) 703 80-87.

43. G. Lanziger, R. Boeck, R. Freudenberger, T. Mehner, I. Scharf, T. Lampke, Trns. Inst. Metal Finishing, 201391 133-140.

44. Joao C. Malaquias, M. Steichen, M. Thomassey, P. J. Dale, Electrochim. Acta, 103 (2013) 15-22.

45. S. Ghosh, S. Roy and K.S. Ryder, Trans. Met. Finishing (September, 2013) proofing stage.

46. K. Haerens, E. Matthijs, K. Binnemans and B.-V. der Bruggen, Green Chem. 200911 $1357-1365$.

47. C. P. D. Leon and F. C. Walsh, Trans. Inst. Met. Finishing. 81(5) (2003) B95-B100. 
48. R. G. Evans, O. V. Klymenko, P. D. Price, S. G. Davies, C. Hardacre and R. G. Compton, ChemphysChem, 6, 526-533 (2005).

49. JSPDS number- 00-004-0836, T. Swanson, Natl. Bur. Stand. (U.S.), Cric. 539, I, (1953) 15.

50. V. K. Pecharsky and P. Y. Zavalij (eds.) Fundamentals of Powder Diffraction and Structural Characterization of Materials, $2^{\text {nd }}$ ed. Springer (2008), pp. 266, 352-354.

51. P. Scherrer, Gottinger Nachrichten Gesell. 2 (1918) p 98. (as referred to in B. D. Cullity and S. R. Stock, Elements of X-ray Diffraction, $3^{\text {rd }}$ Ed. Prentice Hall Inc. , 2001, pp. 167-171.

52. S.J. Skrzypek, W. Ratuszek, A. Bunsch, M. Witkowska, J. Kowalska, M. Goly, K. Chruściel, Journal of Achievements in Materials and Manufacturing Engineering, 43 (1) (2010) 264-268.

53. R. P. Vinci, E. M. Zielinski and J. C. Bravman, Thin Solid Films 262 (1995) 142-153.

54. G. K. Williamson and W. H. Hall, Acta Metallurgica 1 (1953) 22-31.

55. R. Brüning, B. Muir, E. McCalla, É. Lempereur, F. Brüning and J. Etzkorn, Thin Solid Films 519 (2011) 4377-4383.

56. T.-I. Leong, I. W. Sun, M.-J. Deng, C.-M. Wu and P.-Y. Chen, J. Electrochem. Soc., 155, (2008) F55-F60. 
Table 1:

Reactions forming ethaline and speciation of $\mathrm{Cu}^{2+}$ in the Melt

\begin{tabular}{|c|c|c|}
\hline & Reaction scheme in the mixture & Complexes in the ethaline melt \\
\hline $\begin{array}{l}\text { Formation } \\
\text { of the } \\
\text { ethaline } \\
\text { Melt }\end{array}$ & $\begin{array}{c}{\left[\mathrm{HOC}_{2} \mathrm{H}_{4} \mathrm{~N}\left(\mathrm{CH}_{3}\right)_{3}{ }^{+}\right]\left[\mathrm{Cl}^{-}\right]+\left[\mathrm{OHCH}_{2} \mathrm{CH}_{2} \mathrm{OH}\right]} \\
\qquad \\
{\left[\mathrm{HOC}_{2} \mathrm{H}_{4} \mathrm{~N}\left(\mathrm{CH}_{3}\right)_{3}{ }^{+}\right]+\left[\mathrm{OHCH}_{2} \mathrm{CH}_{2} \mathrm{OH}\right] \mathrm{Cl}^{-}}\end{array}$ & Ethylene glycol \\
\hline $\begin{array}{l}\text { Cupric ion } \\
\text { speciation } \\
\text { in ethaline } \\
\text { DES }\end{array}$ & $\begin{array}{l}\text { 1. } \mathrm{Cl}^{-}+\mathrm{CuCl}_{2} \leftrightarrow\left[\mathrm{CuCl}_{3}\right]^{-} \\
\text {Followed by } \\
\text { 2. } \mathrm{Cl}^{-}+\left[\mathrm{CuCl}_{3}\right]^{-} \leftrightarrow\left[\mathrm{CuCl}_{4}\right]^{2-} \\
{\left[\mathrm{CuCl}_{4}\right]^{2-} \text { is the stable electroactive species. }}\end{array}$ & $\mathrm{Cl} \searrow_{\mathrm{Cl}}^{\mathrm{Cu}^{2-}} \mathrm{Cl}$ \\
\hline
\end{tabular}




\section{Table 2:}

Mass transfer limiting currents for $\mathrm{Cu}^{+}$reduction for $0.05 \mathrm{M}$ and $0.2 \mathrm{M} \mathrm{CuCl}_{2}$ in pure ethaline at $700 \mathrm{rpm}$ and $1300 \mathrm{rpm}$

\begin{tabular}{|l|l|l|l|l|}
\hline $\mathrm{C}_{\mathrm{b}}(\mathrm{M})$ & $\omega(\mathrm{rpm})$ & $\begin{array}{l}\text { Experimental } \\
\text { limiting current } \\
\left(\mathrm{A} / \mathrm{cm}^{2}\right)\end{array}$ & $\begin{array}{l}\text { Experimental ratio } \\
\text { of limiting currents }\end{array}$ & $\begin{array}{l}\text { Theoretical ratio of } \\
\text { limiting current }\end{array}$ \\
\hline 0.05 & 700 & -0.0014 & 1.0 & 1.0 \\
\hline 0.05 & 1300 & -0.0020 & 1.42 & 1.36 \\
\hline 0.2 & 700 & -0.0060 & 4.28 & 4.0 \\
\hline 0.2 & 1300 & -0.0070 & 5.0 & 5.44 \\
\hline
\end{tabular}




\section{Table 3:}

Duration of experiments and corresponding metal plated out during long term $\mathrm{Cu}$ deposition from ethaline- $\mathrm{CuCl}_{2} \cdot 2 \mathrm{H}_{2} \mathrm{O}$. The table shows the anodes used during the experiment and the variation in monitored cell potential.

\begin{tabular}{|c|c|c|c|}
\hline Type of anode & $\begin{array}{c}\text { Metal deposited out } \\
\text { Moles/ }(\mu \mathrm{m})\end{array}$ & $\begin{array}{c}\text { Duration of } \\
\text { operation } \\
\text { (hours) }\end{array}$ & $\begin{array}{c}\text { Cell potential } \\
\text { (V) } \\
\text { Start/End* }\end{array}$ \\
\hline Pt mesh & $0.018 / 200$ & 28 & 0.65 to 0.55 \\
\cline { 3 - 4 } & $0.017 / 192$ & 26 & 0.58 to 0.53 \\
\hline & & & 0.60 to 0.55 \\
\hline
\end{tabular}

*The cell potential corresponds to the values observed at the start of plating each time (upper row) and the end of plating each time (lower row). 


\section{Figure captions}

Figure 1

Cell arrangement for potentiostatic deposition showing the jacketed cell used in the polarisation and deposition experiments. The potentiostat was replaced by a power supply during galvanostatic experiments.

Figure 2

Polarisation data of copper reduction using Pt electrode at $25{ }^{\circ} \mathrm{C}$, with a scan rate of $30 \mathrm{mV} / \mathrm{s}$ from electrolytes as (a) ethaline $+0.05 \mathrm{M} \mathrm{CuCl}_{2} .2 \mathrm{H}_{2} \mathrm{O}$, (b) ethaline $+0.2 \mathrm{M} \mathrm{CuCl}_{2} .2 \mathrm{H}_{2} \mathrm{O}$, and RDE speeds of (-) $700 \mathrm{rpm}$ and (...) $1300 \mathrm{rpm}$. The scanning commenced at the open circuit potential of $0.0 \mathrm{~V}$.

Figure 3

$\mathrm{Cu}$ deposition on stainless steel substrate by applying a constant potential of $-0.6 \mathrm{~V}$ from ethaline melt containing metal ions at $25{ }^{\circ} \mathrm{C}$. The total time of deposition was $3600 \mathrm{~s}$. Micrographs for $0.05 \mathrm{M} \mathrm{CuCl}_{2} .2 \mathrm{H}_{2} \mathrm{O}$ at a rotation speed of $700 \mathrm{rpm}$ [A], $0.2 \mathrm{M} \mathrm{CuCl}_{2} .2 \mathrm{H}_{2} \mathrm{O}$ at a rotation speed of $700 \mathrm{rpm}$, and $0.2 \mathrm{M} \mathrm{CuCl}_{2} \cdot 2 \mathrm{H}_{2} \mathrm{O}$ at a rotation speed of $1300 \mathrm{rpm}$ [C].

Figure 4

Micrographs of galvanostatic copper deposition at a current density of $-4.7 \times 10^{-3} \mathrm{~A} / \mathrm{cm}^{2}$ from an ethaline melt at $25^{\circ} \mathrm{C}$ containing $0.2 \mathrm{M} \mathrm{CuCl}_{2} .2 \mathrm{H}_{2} \mathrm{O}$. The total time of deposition was 1800 $\mathrm{s}$ and $\mathrm{RDE}$ speed of $700 \mathrm{rpm}$. [A] Top view, and [B] cross sectional view.

Figure 5

XRD pattern of the $\mathrm{Cu}$ deposit on stainless steel substrate for a sample plated under conditions shown in figure 4. The total time of deposition was $3600 \mathrm{~s}$ to ensure that the deposit was thick. The peaks corresponding to [-] $\mathrm{Cu},[-] \mathrm{Fe}-\mathrm{Cr},[-] \mathrm{PTFE}$ are shown. Grain size calculations were carried out using the peaks corresponding to (a), (b) and (c).

Figure 6

Zoom of the peaks corresponding to (a), (b) and (c) as mentioned in fig 5. The figures show the deconvoluted data and the line broadening data used for calculations.

Figure 7

Colour of freshly prepared ethaline- $0.2 \mathrm{M} \mathrm{CuCl}_{2} \cdot 2 \mathrm{H}_{2} \mathrm{O}$ melt [1]. The colour of the melt after a period of deposition [2], using a soluble anode (A), and inert anode (B).

Figure 8

Potential scan showing electrochemical window of ethaline at Pt RDE, scan rate $30 \mathrm{mV} / \mathrm{s}$, $25^{\circ} \mathrm{C}$ and $\mathrm{RDE}$ speeds as (....) $100 \mathrm{rpm},(-) 2500 \mathrm{rpm}$. The data show low cathodic currents at overpotentials where $\mathrm{Cu}$ would be deposited. 


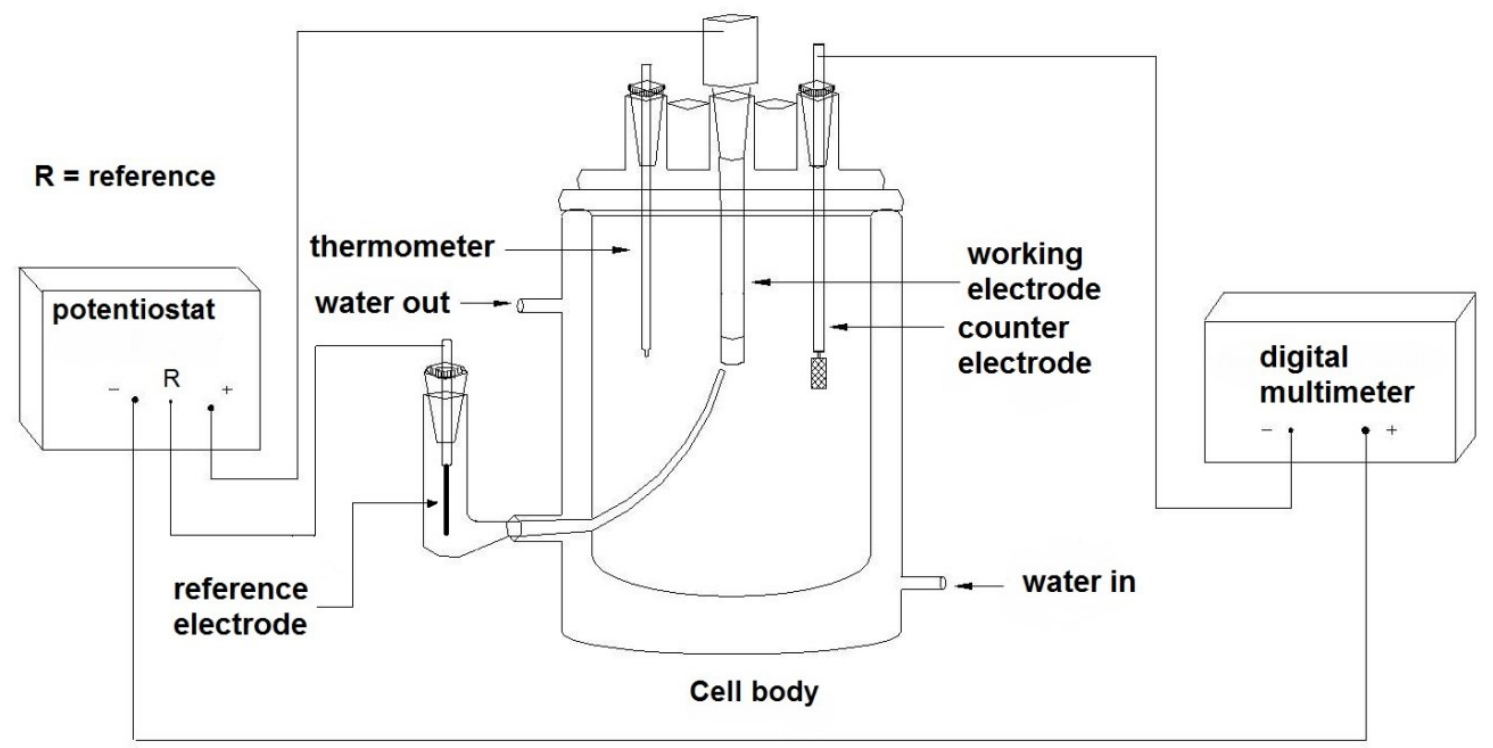

Figure 1 

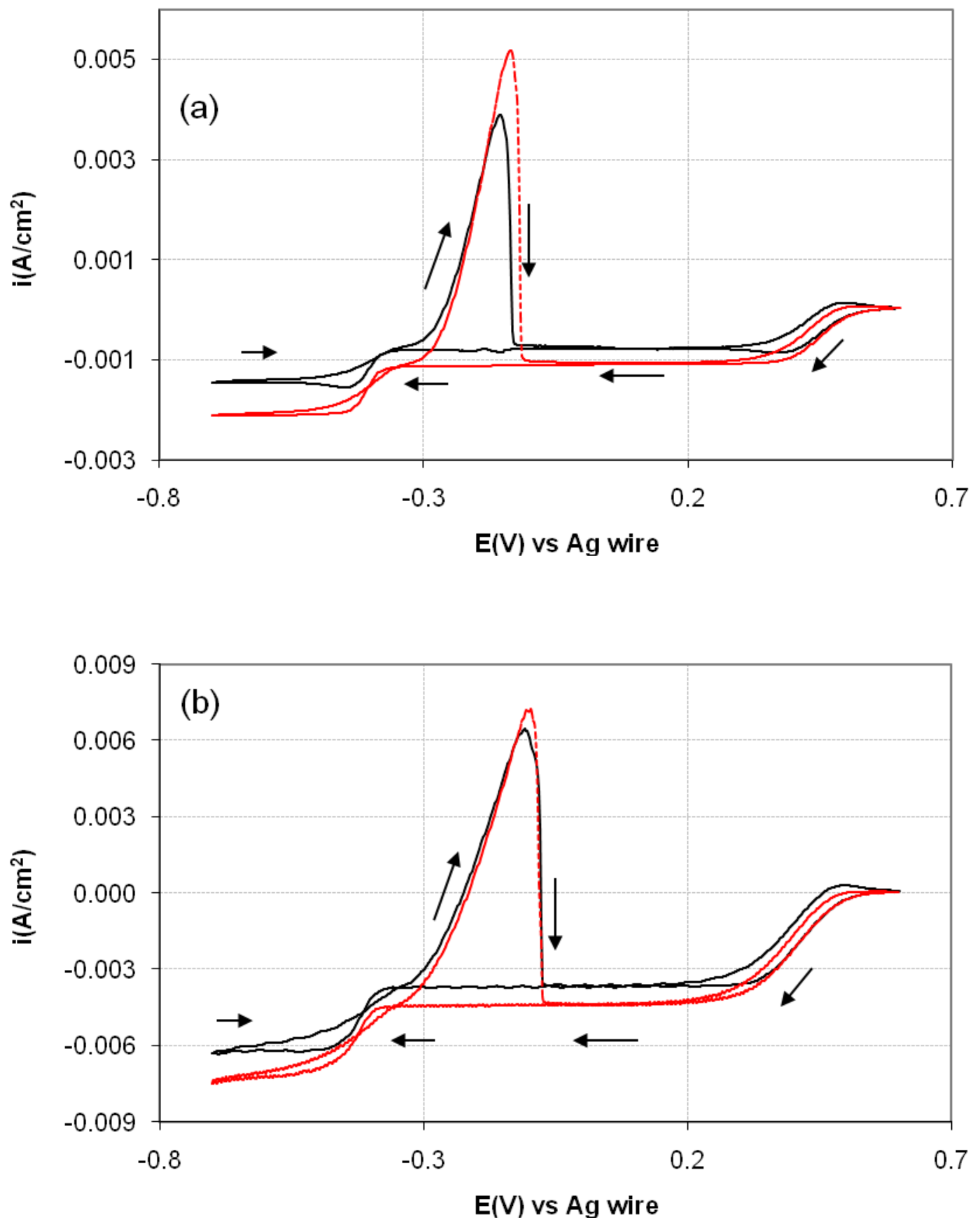

Figure 2 

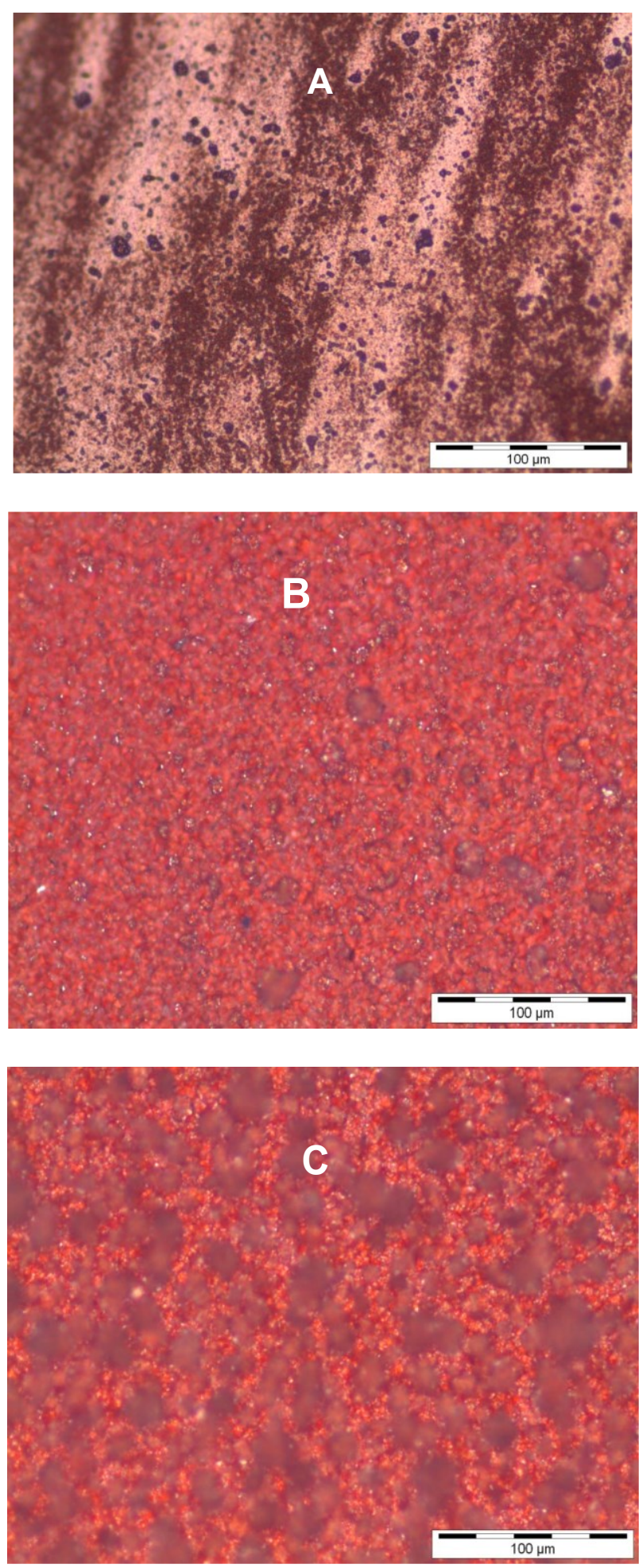

Figure 3 

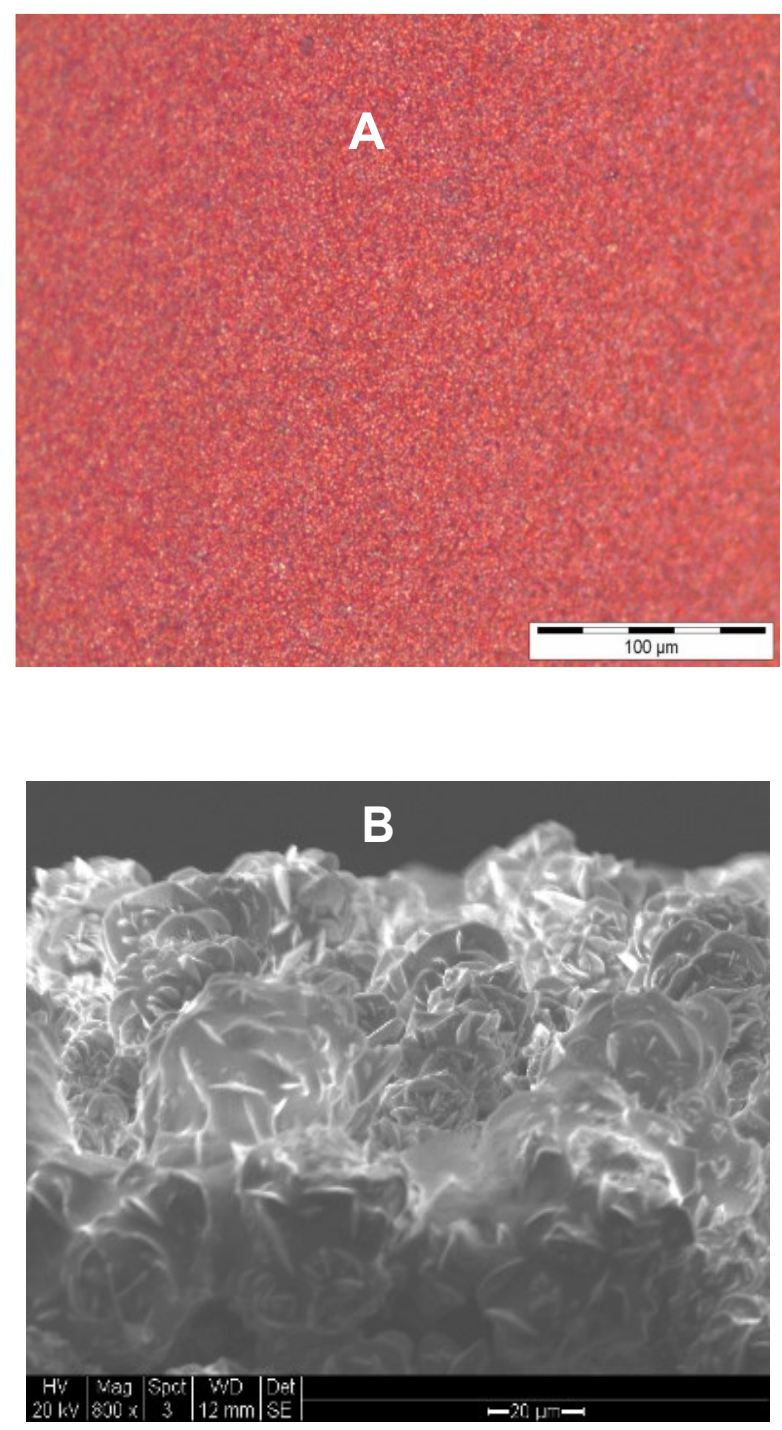

Figure 4 

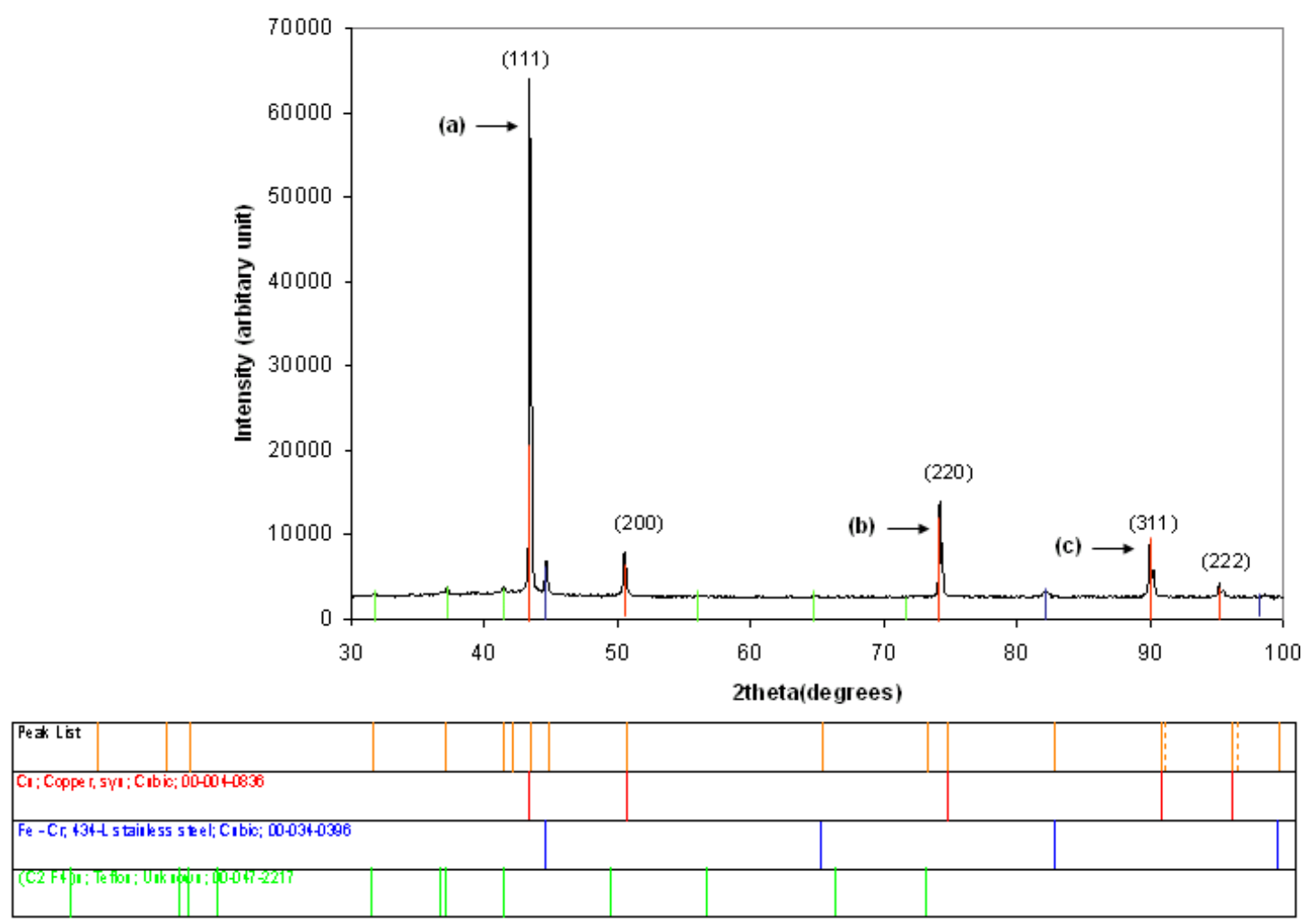

Figure 5 

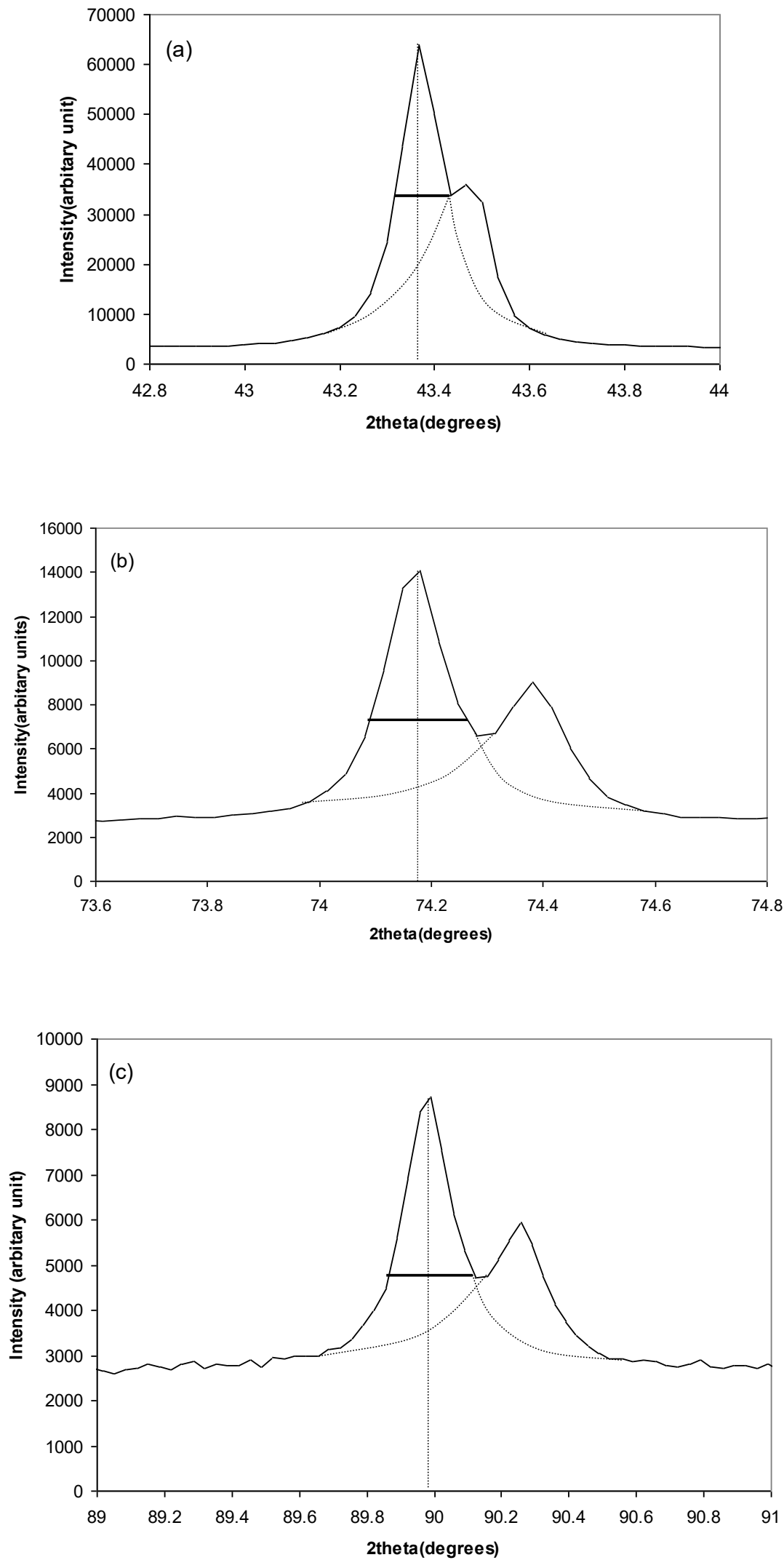

Figure 6 


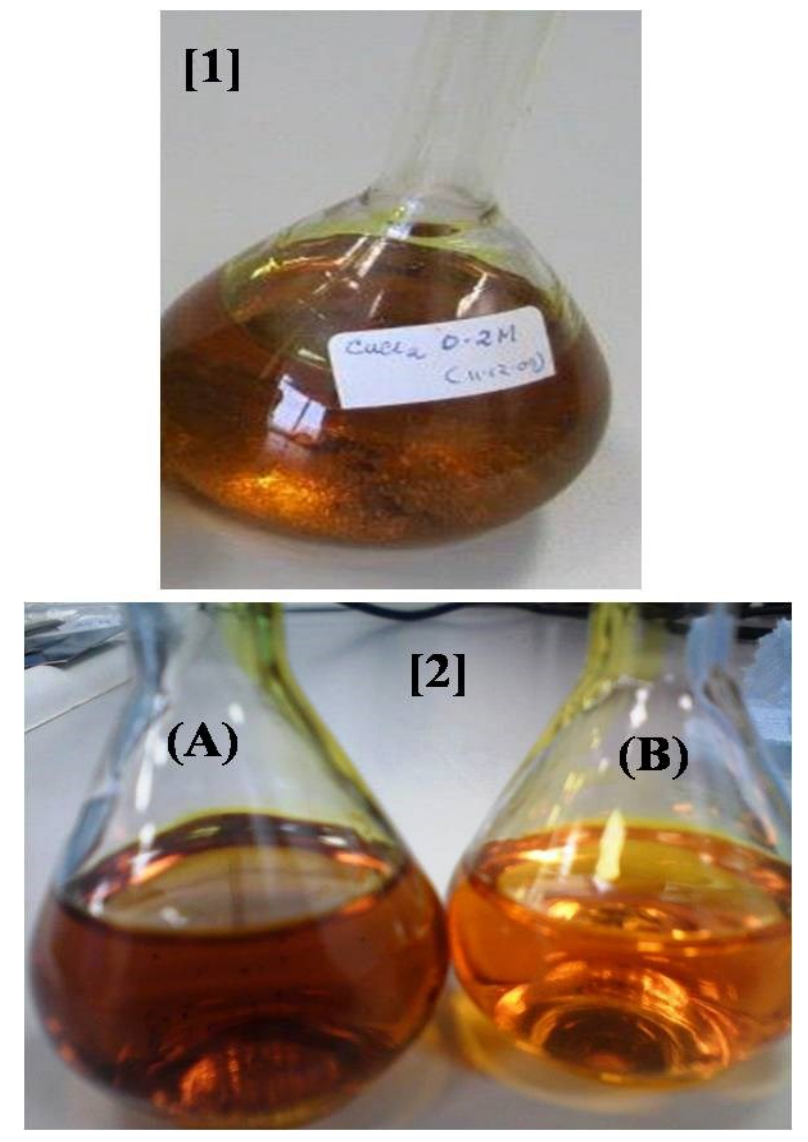

Figure 7 


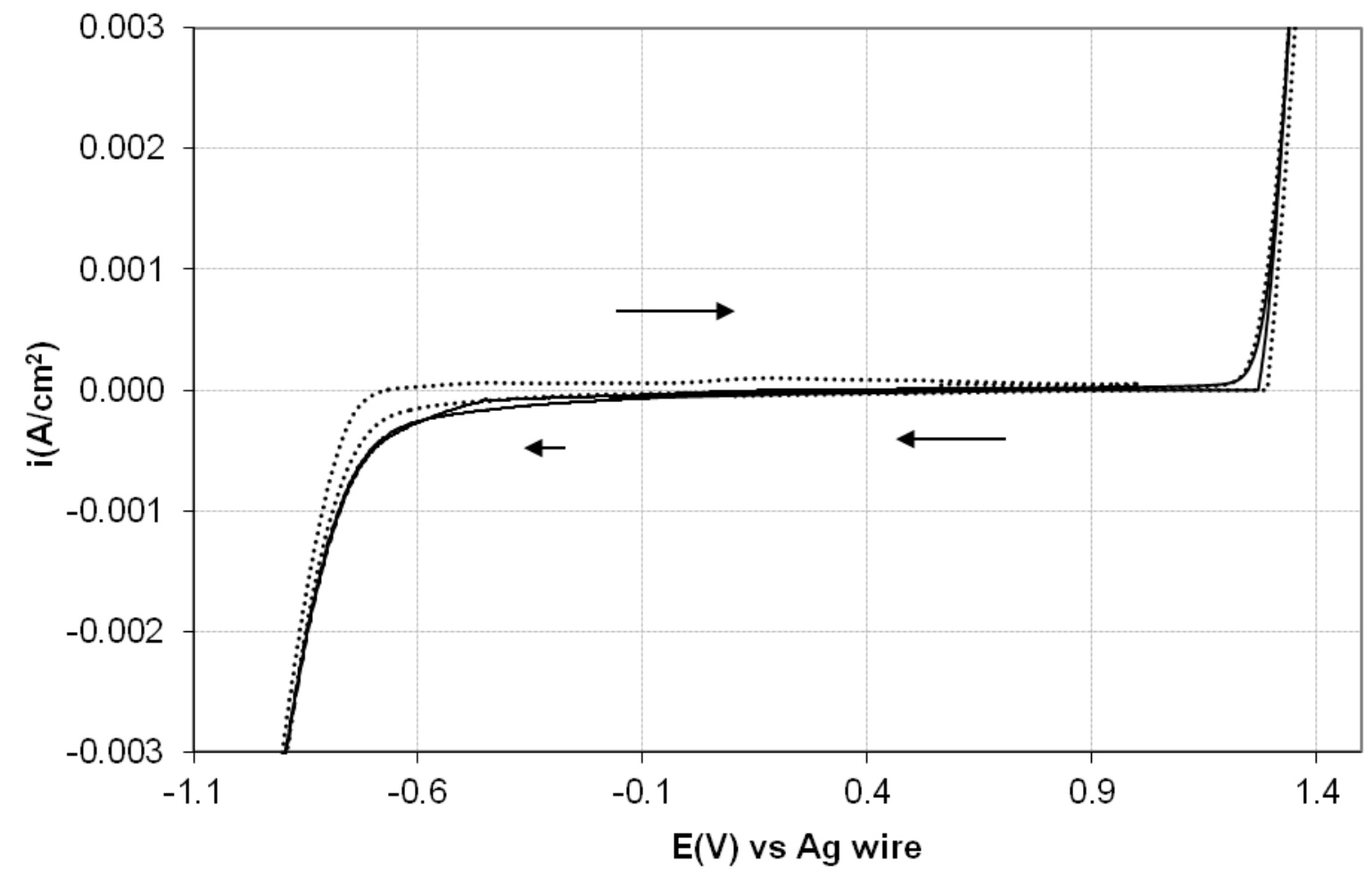

Figure 8 